\title{
Effects of estuarine acidification on predator-prey interactions
}

\author{
Valter Amaral $^{1,2, *}$, Henrique N. Cabral ${ }^{1}$, Melanie J. Bishop ${ }^{2}$ \\ ${ }^{1}$ Centro de Oceanografia, Faculdade de Ciências da Universidade de Lisboa, Campo Grande, 1749-016 Lisboa, Portugal \\ ${ }^{2}$ Department of Biological Sciences, Macquarie University, North Ryde, New South Wales 2109, Australia
}

\begin{abstract}
Short-term experiments exposing calcifying organisms to acidification have revealed altered growth and strength of their exoskeletons. We tested the hypothesis that multi-generational exposure to sustained estuarine acidification from runoff from acid sulphate soils (ASS) would: (1) reduce the shell strength of sessile or relatively immobile wild benthic invertebrates and (2) as a consequence render these invertebrates that rely on armour for anti-predator defence more susceptible to generalist benthic predators. First, we compared the force required to break the exoskeletons of Saccostrea glomerata, Bembicium auratum, and Heloecius cordiformis between replicate south-east Australian mangrove forests close to (acidified) and away from (reference) major ASS outflow drains. Second, we assessed differences in the susceptibility of oysters from acidified and reference forests to predation by the generalist muricid gastropod Morula marginalba. Mollusc shells were significantly weaker at ASS-affected than at reference sites, but the strength of crab carapaces was not influenced by acidification. Oysters from acidified sites were consumed by $M$. marginalba at a faster rate than oysters from reference sites in choice and nochoice experiments because $M$. marginalba required less time to drill through weaker shells. Many other predators such as crabs are generalist feeders that consume prey at rates inversely proportional to their shell strength. Hence, in the absence of effects of acidification on the ability of these predators to consume prey, molluscs at acidified sites may also be more susceptible to other such predators. This study highlights how human stressors can rapidly alter predator-prey interactions that have evolved over many years.
\end{abstract}

KEY WORDS: Acidification - Anti-predator defence $\cdot$ Armouring $\cdot$ Crabs $\cdot$ Macroinvertebrates Oysters $\cdot \mathrm{pH} \cdot$ Predation

\section{INTRODUCTION}

Predation plays a central role in determining the structure of populations, communities, and ecosystems (e.g. Murdoch \& Oaten 1975, Seitz et al. 2001). At the population level, predation can influence the biology and ecology of prey species by selecting for traits that lower the success of the predator in encountering, detecting, identifying, attacking, capturing, and/or consuming that species (Vermeij 1982). Some predators may, in return, have the capacity to evolutionarily respond to changes in anti-predator defences (Vermeij 1994). Nevertheless, over thousands of years, selection generally favours prey with anti-predator responses that are well adapted to the predatory selection regime (Vermeij 1987).

Increasingly, the selection of particular morphological and behavioural traits that have emerged over millennia is rapidly being reversed by human activities that modify these at time scales as short as years or even days (Byers 2002). Where these traits are important in anti-predator defence or predator success, major changes in predator-prey interactions can result (Byers 2002). For example, the continual expo- 
sure of mammals and birds to human stimuli in urban areas can reduce their anti-predator responses involving vigilance behaviour through a process of habituation (e.g. Metcalf et al. 2000, Magle et al. 2005). In marine sediments, the induction of hypoxia can enhance the predatory mortality of burrowing, infaunal species by causing them to spend longer at, or close to, the sediment surface where they are more vulnerable to visually-feeding predators (e.g. Taylor \& Eggleston 2000, Byers et al. 2010).

Within coastal ecosystems, bivalves, gastropods, and crustaceans generally have anti-predator responses that can be categorized as: (1) morphological barriers that increase handling time ('armoring'; Vermeij 1987); and/or (2) density or habitat refuges that reduce a predator's encounter rate ('avoidance'; Sponaugle \& Lawton 1990). Species at the armoured end of the spectrum are typically on full display to predators and gain 'coexistence refugia' (Menge \& Lubchenco 1981) due to their difficulty in being handled. This is possible because many benthic predators such as crabs, naticid and muricid gastropods, and fishes are generalist feeders, consuming those prey items that yield within a certain time (e.g. Fairweather \& Underwood 1983, Brown \& Haight 1992, Hartman 2000, Bishop et al. 2008). Among armoured species, processes that weaken shell thickness or strength may confer greater vulnerability to predation (e.g. Seed \& Hughes 1995, Bishop \& Peterson 2006, Newell et al. 2007).

Ocean acidification is among the anthropogenically enhanced processes that may modify the efficacy of exoskeletons in protecting animals from predation. In laboratory and field experiments, a high proportion of calcifying marine organisms has been observed to exhibit change in net calcification following transplant to $\mathrm{CO}_{2}$-enriched waters, sometimes of a positive and sometimes of a negative direction (e.g. Ries et al. 2009, Rodolfo-Metalpa et al. 2011). As $\mathrm{CO}_{2}$ concentrations increase, impacts to net calcification become increasingly negative, because any enhancement of growth and calcification by $\mathrm{CO}_{2}$ is outweighed by the high rates of shell dissolution that occur at low pH (Rodolfo-Metalpa et al. 2011). Under such conditions, animals may lose their ability to adequately protect themselves against predators by using morphological barriers (Bibby et al. 2007).

In addition to $\mathrm{CO}_{2}$ acidification, many estuaries are presently experiencing acidification from acid sulphate soils (ASS). ASS occur on all continents of the world (Dent \& Pons 1995) and can locally reduce the $\mathrm{pH}$ of adjacent estuarine waters to as low as 2 to 6 where networks of drainage channels and flood- gates concentrate runoff from the adjacent land (Sammut et al. 1996, NSW DPI 2006). In many cases, exposure of estuarine ecosystems to ASS runoff has spanned several decades, providing an ideal model system in which to assess multi-generational impacts of low $\mathrm{pH}$ on calcifying organisms and their predator-prey interactions. Studies with oysters never before exposed to ASS runoff have shown that short-term exposure to acidified waters both in the laboratory and in the field can cause significant shell dissolution and perforation of juvenile oysters (Dove \& Sammut 2007a,b). It is unclear whether bivalves, gastropods, and crustaceans that have been exposed to ASS runoff over multiple generations display the same response.

We investigated the long-term effects of estuarine acidification on the structural defences of mangrove invertebrates in estuaries of New South Wales (NSW), Australia. First, we tested for differences in the strength of the exoskeleton of: (1) sessile and mobile molluscs and (2) crabs, between areas close to and away from major ASS outflow drains. Sessile molluscs, mobile molluscs, and crabs represent the full spectrum of the armour-avoidance prey-defence continuum. Sessile molluscs rely almost entirely on armouring as protection against predation; mobile gastropods utilise a combination of armour and avoidance; and crabs have only a weak exoskeleton, depending more on avoidance (burial) or escape responses. We predicted that across all taxa, exoskeletons would be weaker in areas closer to drains, and that exoskeleton weakening would be most pronounced among sessile oysters, followed by gastropods and crabs, such that impact is also correlated with dependence on armouring. Second, we assessed whether a reduction of the strength of oyster shells leads to enhanced predation by a carnivorous muricid, the mulberry whelk Morula marginalba. M. marginalba is a generalist predator on intertidal rocky shores that displays highly variable handling times among its prey species according to their mechanical, behavioural, and chemical defences (Fairweather \& Underwood 1983). On rocky shores, dead oysters are frequently found with a drill hole, indicative of predation by $M$. marginalba (Moran et al. 1984) or the mussel drill Bedeva hanleyi, another muricid gastropod that is locally common (Bishop et al. 2010). Using prey choice and no-choice laboratory experiments, we tested the hypothesis that oysters from sites close to drains would be preyed on at a greater rate than oysters from reference sites due to the shorter handling time required to penetrate the former. 


\section{MATERIALS AND METHODS}

\section{Strength of mollusc shells and crab carapaces}

To test the hypothesis that exposure to acidified waters would weaken the exoskeleton of calcifying invertebrates, we collected: (1) gold-mouthed top shells Bembicium auratum and semaphore crabs Heloecius cordiformis from acidified and reference sites within each of the Hunter and Port Stephens estuaries, NSW, Australia during the summer of 2010; and (2) Sydney rock oysters Saccostrea glomerata from each of these 2 estuaries and a third estuary, the Hastings, during fall 2009. Within each estuary, we collected invertebrates from 2 acidified and 2 reference sites situated in intertidal mangrove forests, dominated by the grey mangrove Avicennia marina (Table 1). We measured water $\mathrm{pH}$, temperature, and salinity at each sampling site at 8 randomly selected sampling times between April 2009 and February 2010 using a multi-parameter, handheld, water quality meter (CyberScan PCD 650, Eutech Instruments). Acidified sites were within $900 \mathrm{~m}$ of major ASS outflow drains, at locations where we had recorded depressed $\mathrm{pH}$, and there was a history of low $\mathrm{pH}$ (Table 1). Reference sites were situated $2400 \mathrm{~m}$ from drains, at locations classified as being of low ASS runoff risk (Naylor et al. 1998), and at which we had not observed $\mathrm{pH}$ to drop below 7.7 (Table 1). All sites were of similar water temperature $\left(22\right.$ to $\left.23^{\circ} \mathrm{C}\right)$, but sites adjacent to drains were of slightly lower ( 1 PSU) salinity (Table 1).
At each sampling site, Saccostrea glomerata formed dense aggregations attached to pneumatophores. S. glomerata and Bembicium auratum, which was found within oyster clumps, were collected from at least 15 randomly selected pneumatophores per site, at a mid-tidal elevation (mean low water +0.5 to $0.7 \mathrm{~m}$ ). Heloecius cordiformis were hand-collected from the same mid-shore elevation. Upon collection, the maximal shell height of oysters and gastropods, and the maximal carapace width of crabs were determined using Vernier callipers (0.01 $\mathrm{mm}$ precision). The right (upper) valves (the shell-half most exposed to predators) of oysters were then oven-dried at $65^{\circ} \mathrm{C}$ for $24 \mathrm{~h}$ in preparation for strength testing. Oyster shells were dried prior to testing to prevent variable water retention by their highly heterogeneous surfaces from confounding measurements. Previous studies have shown that drying mollusc shells below $90^{\circ} \mathrm{C}$ does not affect shell resistance to crushing (Currey 1979). Gastropods and crabs, by contrast, had more homogenous surfaces that could be effectively towel-dried. These were tested wet and whole, because attempts to separate their flesh from their shell for drying caused damage to their exoskeleton.

We determined the force (Newtons) required to fracture the shells of oysters and gastropods and the carapaces of crabs using the Instron Universal testing system. Force was applied to each specimen via a probe travelling at $1.7 \mathrm{~mm} \mathrm{~s}^{-1}$ until the specimen failed. We used a $2 \mathrm{~mm}$ diameter probe for mollusc shells and a $1 \mathrm{~mm}$ diameter probe for crabs. Oyster right valves and crab carapaces were orientated so

Table 1. Mean $( \pm \mathrm{SE})$ environmental conditions (Temp = temperature; salinity, $\mathrm{pH}$ ) at each of our study sites in the year prior to our study ( $\mathrm{n}=8$ sampling times). Within the Hunter $(\mathrm{H})$, Port Stephens (P), and Hastings (S) estuaries, acidified (A1, A2) and reference $(\mathrm{R} 1, \mathrm{R} 2)$ sites were selected on the basis of these measurements, previously recorded $\mathrm{pH}$ minima ( $\mathrm{pH}$ min) and acid sulphate risk maps that categorise areas according to the probability that they are impacted by this disturbance (ASS risk; Naylor et al. 1998)

\begin{tabular}{|c|c|c|c|c|c|c|c|c|}
\hline Site & Location & $\begin{array}{l}\text { Latitude } \\
\text { South }\end{array}$ & $\begin{array}{c}\text { Longitude } \\
\text { East }\end{array}$ & $\begin{array}{l}\text { Temp } \\
\left({ }^{\circ} \mathrm{C}\right)\end{array}$ & Salinity & $\mathrm{pH}$ & $\begin{array}{l}\mathrm{pH} \\
\min \end{array}$ & $\begin{array}{l}\text { ASS } \\
\text { risk }\end{array}$ \\
\hline HA1 & Fullerton Cove & $32^{\circ} 50^{\prime} 37^{\prime \prime}$ & $151^{\circ} 48^{\prime} 34^{\prime \prime}$ & $22( \pm 2)$ & $26( \pm 2)$ & $6.94( \pm 0.09)$ & $\sim 4^{\mathrm{a}}$ & High \\
\hline HA2 & Tomago Wetland & $32^{\circ} 51^{\prime} 07^{\prime \prime}$ & $151^{\circ} 46^{\prime} 05^{\prime \prime}$ & $22( \pm 1)$ & $26( \pm 1)$ & $6.98( \pm 0.12)$ & $\sim 4^{\mathrm{a}}$ & High \\
\hline HR1 & Southern Ash Island & $32^{\circ} 51^{\prime} 43^{\prime \prime}$ & $151^{\circ} 47^{\prime} 03^{\prime \prime}$ & $22( \pm 1)$ & $26( \pm 2)$ & $7.92( \pm 0.05)$ & $\sim 7^{\mathrm{a}}$ & Low \\
\hline HR2 & Northern Ash Island & $32^{\circ} 51^{\prime} 24^{\prime \prime}$ & $151^{\circ} 47^{\prime} 12^{\prime \prime}$ & $23( \pm 2)$ & $27( \pm 1)$ & $7.92( \pm 0.04)$ & $\sim 7^{\mathrm{a}}$ & Low \\
\hline PA1 & Fenninghams Creek (entry) & $32^{\circ} 44^{\prime} 42^{\prime \prime}$ & $152^{\circ} 03^{\prime} 18^{\prime \prime}$ & $22( \pm 1)$ & $30( \pm 3)$ & $6.52( \pm 0.27)$ & $<5^{\mathrm{b}, \mathrm{c}}$ & High \\
\hline PA2 & Fenninghams Creek (middle) & $32^{\circ} 45^{\prime} 11^{\prime \prime}$ & $152^{\circ} 03^{\prime} 06^{\prime \prime}$ & $22( \pm 1)$ & $30( \pm 2)$ & $6.60( \pm 0.23)$ & $<5^{\mathrm{b}, \mathrm{c}}$ & High \\
\hline PR1 & Stuart's Island & $32^{\circ} 44^{\prime} 39^{\prime \prime}$ & $152^{\circ} 01^{\prime} 45^{\prime \prime}$ & $23( \pm 1)$ & $32( \pm 2)$ & $7.93( \pm 0.11)$ & $\sim 6.8^{\mathrm{c}}$ & Low \\
\hline PR2 & $4 \mathrm{~km}$ north of Stuart's Island & $32^{\circ} 45^{\prime} 38^{\prime \prime}$ & $151^{\circ} 59^{\prime} 40^{\prime \prime}$ & $22( \pm 2)$ & $31( \pm 2)$ & $7.88( \pm 0.08)$ & $\sim 6.8^{\mathrm{c}}$ & Low \\
\hline SA1 & Fernbank Creek & $31^{\circ} 24^{\prime} 28^{\prime \prime}$ & $152^{\circ} 31^{\prime} 25^{\prime \prime}$ & $21( \pm 2)$ & $28( \pm 3)$ & $6.75( \pm 0.23)$ & $<4^{\mathrm{d}}$ & High \\
\hline SA2 & Maria River & $31^{\circ} 23^{\prime} 41^{\prime \prime}$ & $152^{\circ} 50^{\prime} 56^{\prime \prime}$ & $22( \pm 1)$ & $28( \pm 2)$ & $6.85( \pm 0.24)$ & $\sim 2^{\mathrm{d}}$ & High \\
\hline SR1 & Settlement Point & $31^{\circ} 24^{\prime} 13^{\prime \prime}$ & $152^{\circ} 53^{\prime} 45^{\prime \prime}$ & $22( \pm 1)$ & $29( \pm 3)$ & $7.72( \pm 0.11)$ & $\sim 6.5^{\mathrm{d}}$ & Low \\
\hline SR2 & Limeburners Creek & $31^{\circ} 24^{\prime} 05^{\prime \prime}$ & $152^{\circ} 53^{\prime} 18^{\prime \prime}$ & $21( \pm 2)$ & $30( \pm 2)$ & $7.82( \pm 0.10)$ & $\sim 6.5^{\mathrm{d}}$ & Low \\
\hline
\end{tabular}

${ }^{\mathrm{a}} \mathrm{NSW}$ DPI (2008); ${ }^{\mathrm{b}} \mathrm{NSW}$ DPI (2006); ${ }^{\mathrm{c} N S W}$ DPI (2009); ${ }^{\mathrm{d}}$ Tulau (1999) 
that their plane was perpendicular to the probe, which was in turn directed at their centre. For gastropods, the vertical probe applied force to the suture between 2 whorls halfway up the gastropod shell. The maximum load on each specimen immediately prior to failure was taken as a measure of strength and was correlated to the height of oyster and gastropod shells or the width of crab carapaces.

Within each estuary, we compared the relationship between the size and exoskeleton strength of each invertebrate species between acidified and reference sites, using linear regression. Replicate sites within estuaries were pooled in analyses because 2-tailed Student's $t$-tests (Zar 1984) revealed that the regression slopes between strength and size of exoskeletons did not differ between these (Table 2). The regression slopes were compared between acidified and reference treatments within each estuary using 2-tailed Student's $t$-tests. The null hypothesis was that the regression slopes would not significantly differ. Analyses were considered significant at $\alpha=0.01$ to correct for the multiple comparisons.

\section{Predation experiments}

We conducted choice and no-choice predation experiments to test the hypothesis that exposure of Saccostrea glomerata to ASS-affected waters over many generations would increase their susceptibility to predation. Oysters, 25 to $30 \mathrm{~mm}$ in shell height
( $\sim 12$ mo old) and sourced from the acidified and reference sites within the Port Stephens Estuary, were offered to individual Morula marginalba that were 20 to $22 \mathrm{~mm}$ in length and collected from Long Reef $\left(33.738^{\circ} \mathrm{S}, 151.310^{\circ} \mathrm{E}\right) \mathrm{NSW}$, Australia, a coastal site that is not exposed to ASS runoff. We used 25 to $30 \mathrm{~mm}$ oysters in our experiments because this size class is: (1) numerically dominant at many of our study sites (Amaral et al. 2011) and (2) may be particularly susceptible to enhanced predatory mortality following shell-weakening because it is towards the upper size limit of Saccostrea spp. that Morula spp. can handle (Taylor 1990, Koh-Siang 1993). The size range of $M$. marginalba was selected based on the availability of animals at the time of our study, and on previous observations that this size range has greater impact on oyster populations than smaller size classes (Moran 1980). The method by which M. marginalba bores a hole in prey species using its radula and protease enzymes is, for a given predator size, independent of the predator's own shell strength. Hence, we assumed that the predator's response would be independent of any shell dissolution that it itself succumbs to at acidified sites.

The oysters used in the experiments were single individuals, separated from one another and scrubbed to remove fouling organisms that may confound experimental results. Individual oysters, not clumps, were used so as to allow us to evaluate selection of single prey items, holding density constant through replacement. Because muricid gastropods prey by

Table 2. Results of 2-tailed Student's $t$-tests comparing the slopes of linear regressions describing the relationship between strength and invertebrate size (oysters, gastropods: shell height; crabs: carapace width) within acidified (A1, A2) and reference (R1, R2) sites of the Hunter River (H), Port Stephens (P) and Hastings (S) estuaries. Within each estuary, sites of a particular treatment (i.e. acidified or reference) were initially compared (Differences between sites). Where no differences were found, data were pooled and differences between acidified (A) and reference (R) treatments were tested at the estuary level (Differences between treatments - pooled data). Terms significant at $\alpha=0.01$ are shown in bold. All data were analysed untransformed

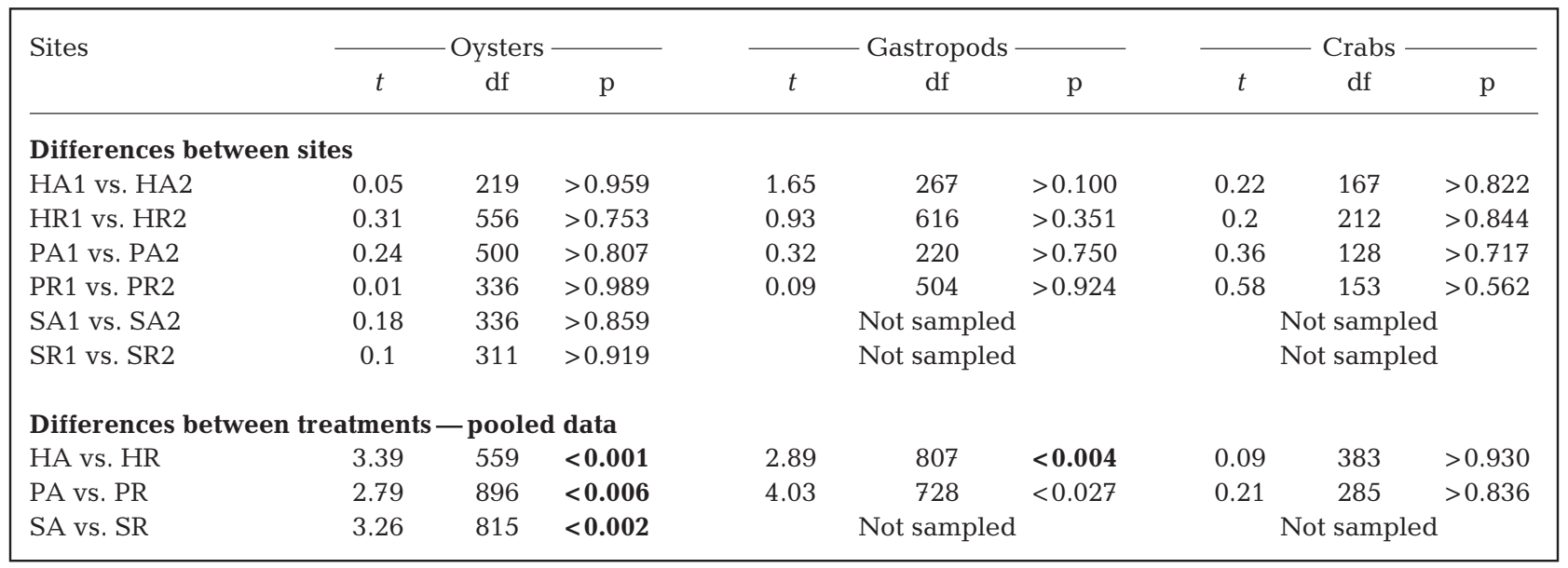


drilling through the right valve of bivalves, rates of predation should not have been unduly influenced by our use of single rather than clumped oysters. Prey and predators were held separately in 401 aquaria prior to experimentation ( 1 wk). Both holding tanks and the smaller 101 aquaria used for experimental trials contained filtered $(<750 \mu \mathrm{m})$ seawater maintained at $22 \pm 1^{\circ} \mathrm{C}$ using electric heaters and a salinity of 32 . Small rocks were introduced to aquaria to provide substrate for animals. White fluorescent tubes ( 80 lux) provided a photoperiod of $14 \mathrm{~h}$ light:10 h dark, approximating natural conditions in NSW at the time of the experiment. Experimental tanks were only partially filled with water to allow Morula marginalba to utilise both emersed and submerged habitat. To prevent M. marginalba from escaping, we applied a $2 \mathrm{~cm}$ wide petroleum jelly band to the wall of mesocosms, $5 \mathrm{~cm}$ above the water surface.

Prior to the start of each experiment, animals were fed in excess every other day - oysters with a commercial shellfish diet of 4 marine microalgae (Shellfish Diet $1800^{\circledR}$, Reed Mariculture), and gastropods with 14 to $17 \mathrm{~mm}$ Saccostrea glomerata obtained from Port Stephens. Just before each feeding, the water within each aquarium was changed. We continued to feed oysters throughout the experiment, but the feeding of whelks was discontinued $48 \mathrm{~h}$ before the commencement of a trial, at which time whelks were placed in $10 \mathrm{l}$ experimental mesocosms (one whelk per tank) for acclimation prior to the addition of prey items. Starving whelks immediately prior to each trial standardized hunger levels.

First, to test whether Saccostrea glomerata from ASS-exposed sites are more susceptible to predation by Morula marginalba than S. glomerata from reference sites, we conducted choice experiments in which we simultaneously offered equal numbers (3) of oysters from acidified (right valve marked with red nail polish) and reference sites to a single M. marginalba ( $\mathrm{n}=18$ replicate trials). Pilot studies indicated that marking oysters with nail polish did not influence predator selection of prey. To maintain independence of replicates, animals and substrata were used only once. Oysters were checked for predation every $12 \mathrm{~h}$, for a period of $10 \mathrm{~d}$. At each observation time, dead (entire, without drill hole) or consumed (with drill hole) oysters were removed from aquaria and replaced with a prey item of similar type. We chose to maintain a constant density of prey items because $M$. marginalba is known to exhibit density-dependent rates of predation on at least some of its prey items (Moran
1985). Where M. marginalba were found sitting on an oyster, the oyster and whelk were not disturbed. We tallied the total number of oysters of each type that were consumed over the $10 \mathrm{~d}$ period, the duration of which was chosen based on rates of prey consumption by $M$. marginalba observed on rocky intertidal shores (Moran 1985). A 1-tailed paired $t$-test ( $\mathrm{n}=18$ trials) evaluated the hypothesis that more oysters from acidified than reference sites would be consumed.

Second, to assess whether in choice experiments any differences in rates of predation on ASSexposed and reference oysters were due to active prey selection by Morula marginalba, or simply due to a reduced handling time for drilling through the weakened shells of acidified oysters, we also conducted no-choice experiments $(\mathrm{n}=18$ replicate trials of each type). In these, we offered 6 oysters either from acidified sites or from reference sites to a single $M$. marginalba. Experimental conditions were otherwise similar to those in choice experiments. Every $12 \mathrm{~h}$ we checked oyster numbers and replaced any dead or consumed individuals. We terminated the trials after $10 \mathrm{~d}$. Under the null hypothesis of no preference for one source of oyster over the other, the expected numbers of acidified or reference oysters consumed by $M$. marginalba in choice experiments were:

$$
\begin{aligned}
& E_{\mathrm{A}}=N_{\mathrm{T}}\left[M_{\mathrm{A}} /\left(M_{\mathrm{A}}+M_{\mathrm{R}}\right)\right] \\
& E_{\mathrm{R}}=N_{\mathrm{T}}\left[M_{\mathrm{R}} /\left(M_{\mathrm{A}}+M_{\mathrm{R}}\right)\right]
\end{aligned}
$$

where $M_{\mathrm{A}}$ and $M_{\mathrm{R}}$ are, respectively, the numbers of acidified and reference oysters consumed when each is presented on its own (in equal numbers) and $N_{\mathrm{T}}$ is the total number of oysters consumed when offered together in choice experiments. We estimated $M_{\mathrm{A}}$ and $M_{\mathrm{R}}$ by summing the number of each species consumed in monospecific trials across independent replicates. We used $\chi^{2}$ goodness-of-fit tests to compare the expected numbers of oysters consumed, $E_{\mathrm{A}}$ and $E_{\mathrm{R}}$, with the numbers of oysters consumed when presented together $\left(N_{\mathrm{A}}\right.$, $N_{\mathrm{R}}$ for oysters from acidified and reference sites, respectively; $N_{\mathrm{A}}+N_{\mathrm{R}}=N_{\mathrm{T}}$ ). Because these $\chi^{2}$ tests are subject to excessive Type I error (see Liszka \& Underwood 1990), only nonsignificant results could be interpreted.

Among no-choice trials, differences in the number of oysters consumed and the average time spent by Morula marginalba consuming them were compared between acidified and reference oysters using 2-sample, 1-tailed $t$-tests. 


\section{RESULTS}

\section{Strength of mollusc shells and crab carapaces}

Within estuaries, regression slopes between animal size and exoskeleton strength did not differ between replicate sites for any of the 3 species considered (Table 2). Consequently, sites could be pooled prior to comparison of treatments (i.e. acidified vs. reference). Analysis of pooled data revealed that within each estuary, the shells of oysters and gastropods were weaker at acidified than reference sites (Figs. 1 $\& 2$ ), although this general trend was not statistically
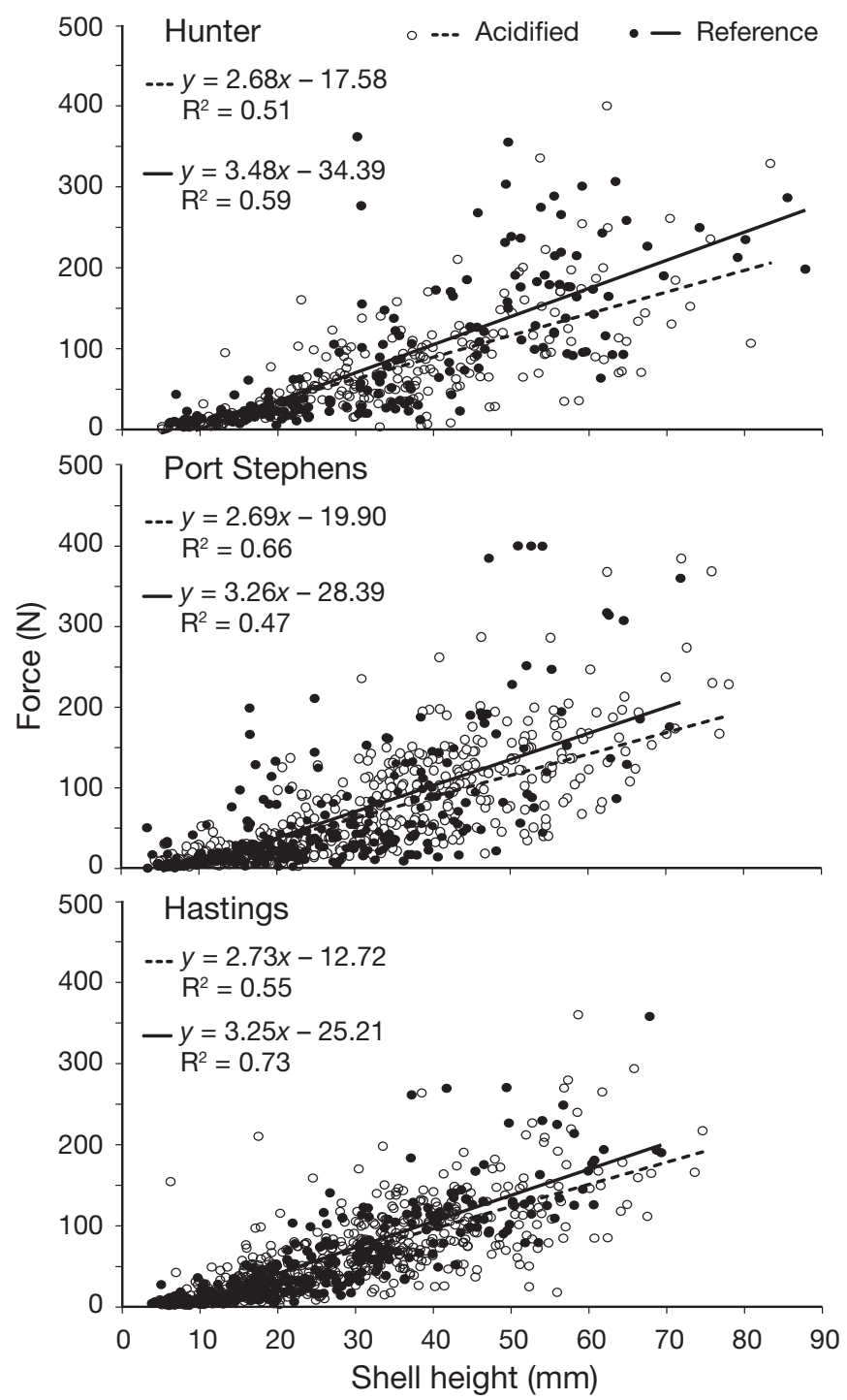

Fig. 1. Force (in Newtons) required to break the shells of Saccostrea glomerata. Within estuaries, data were pooled across replicate sampling sites within a treatment (acidified or reference) because regression slopes did not significantly differ

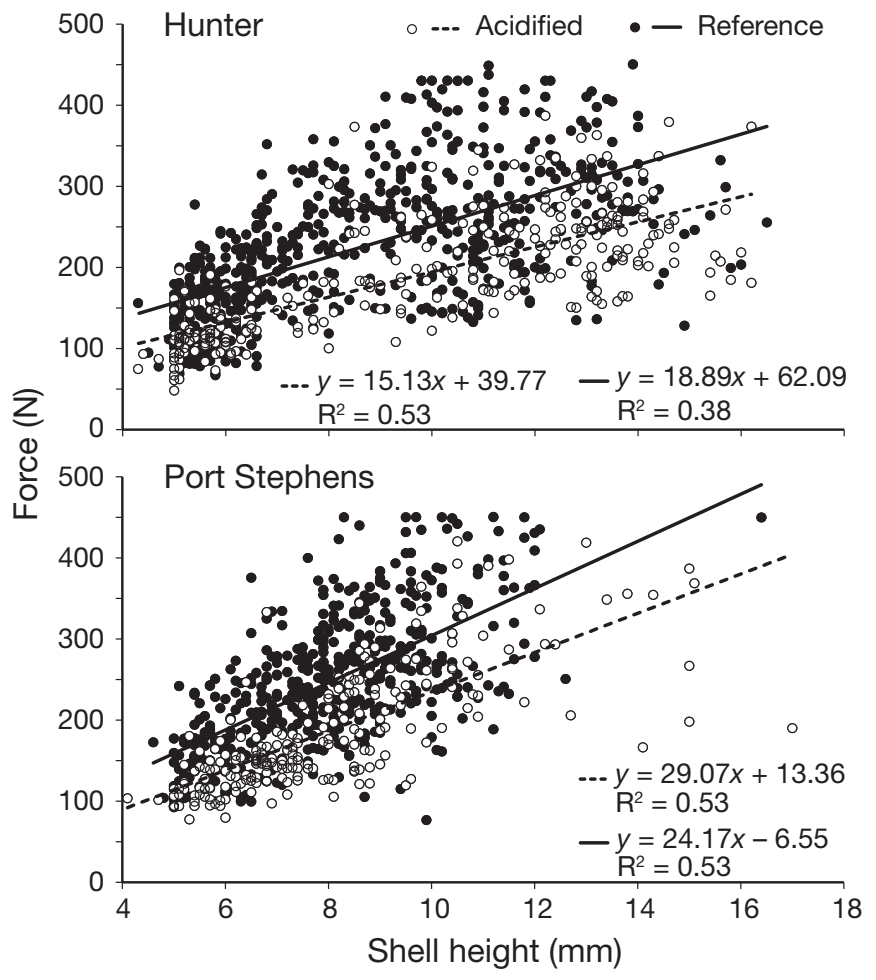

Fig. 2. Force (in Newtons) required to break the shells of Bembicium auratum. Within estuaries, data were pooled across replicate sampling sites within a treatment (acidified or reference) because regression slopes did not significantly differ

significant for gastropods within Port Stephens (Table 2, Fig. 2). By contrast, the strength of crab carapaces did not differ between acidified and reference sites in either of the estuaries (Fig. 3, Table 2). For both oysters and gastropods, the difference in shell strength between acidified and reference sites increased with animal size (Figs. $1 \& 2$ ).

\section{Effect of oyster exposure to ASS runoff on susceptibility to predation by a gastropod}

On average, across all trials, a single Morula marginalba completely consumed $2.5 \pm 0.1($ mean $\pm \mathrm{SE}$ ) oysters within the $10 \mathrm{~d}$ of the experiment. In 9 of the 18 choice trials, M. marginalba consumed more Saccostrea glomerata from acidified than reference sites. In 8 of the 18 trials, M. marginalba consumed equal numbers of oysters from different sources, and in only 1 trial were more oysters from the reference site consumed. Consequently, across all 18 choice trials, M. marginalba consumed significantly more oysters from acidified $\left(1.7 \pm 0.2\right.$ ind. trial $\left.^{-1}\right)$ than reference $\left(1.0 \pm 0.1 \mathrm{ind}\right.$. trial $\left.^{-1}\right)$ sites (1-tailed paired $t$-test: $t=$ 2.92, df $=17, \mathrm{p}<0.005$; Fig. 4 ), overall by $67 \%$. 


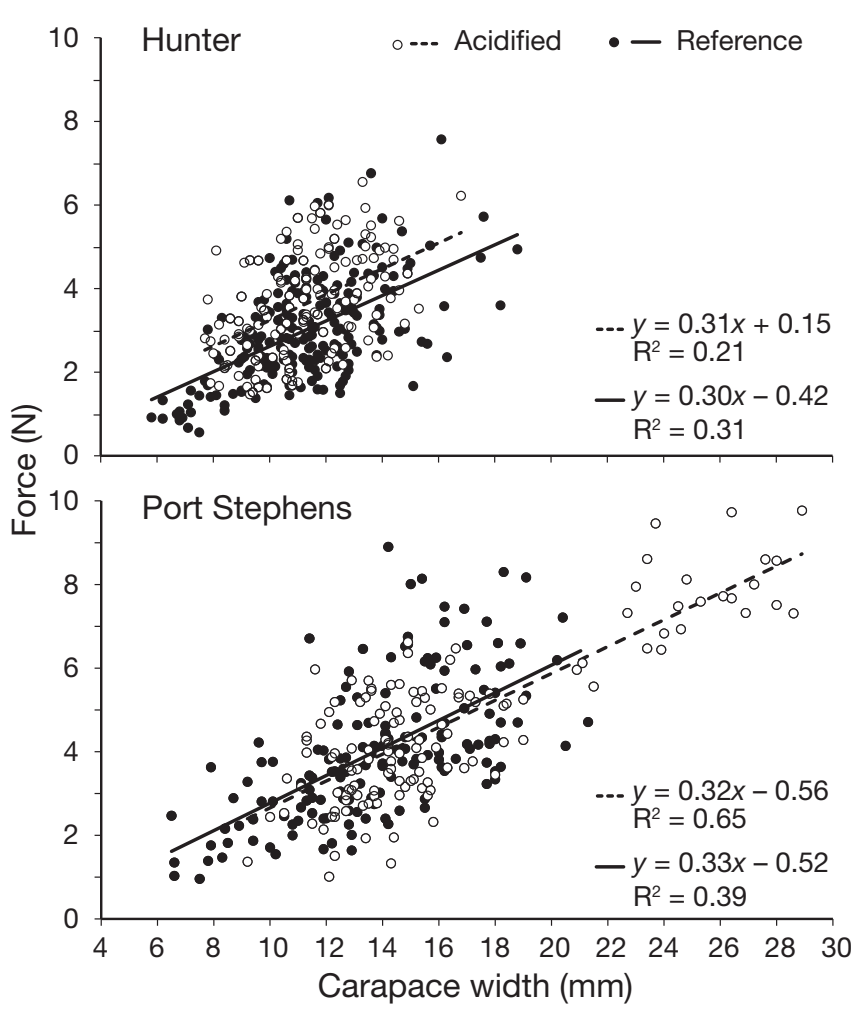

Fig. 3. Force (in Newtons) required to break the carapaces of Heloecius cordiformis. Within estuaries, data were pooled across replicate sampling sites within a treatment (acidified or reference) because regression slopes did not significantly differ

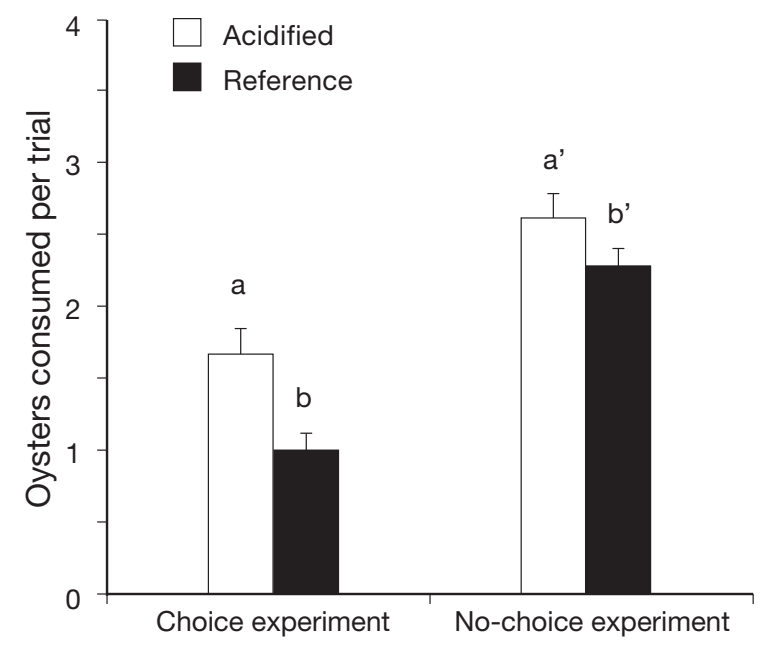

Fig. 4. Mean (+SE) number of Saccostrea glomerata consumed by Morula marginalba during $10 \mathrm{~d}$ trials in which predators were offered equal numbers of prey from acidified and reference sites (choice experiment) or were offered only a single prey type (no-choice experiment). Oysters were replaced whenever consumed or dead to maintain a constant density of 6 oysters per replicate. Bars that do not share letters are significantly different at $\mathrm{p}<0.05 . \mathrm{n}=18$
Among the 18 choice trials, $M$. marginalba attacked an acidified oyster first in half the trials (9). Despite the identical probability of a whelk attacking an acidified or reference oyster first, in 15 of the 18 trials the second oyster consumed was from an acidified site. Of the 12 whelks that consumed a reference oyster as either their first or second prey item, only 5 went on to consume additional ( 3 to 4 total) prey. By contrast, 5 of the 6 whelks that consumed acidified oysters as both their first and second prey items went on to consume additional oysters. No whelk was observed to consume 2 reference oysters in a row, whereas whelks consumed 2 acidified oysters in a row in half (9) of the trials.

Among the no-choice trials, Morula marginalba also consumed more oysters sourced from acidified $\left(2.6 \pm 0.2\right.$ ind. trial $\left.{ }^{-1}\right)$ than reference $(2.3 \pm 0.1$ ind. trial $^{-1}$ ) sites (1-tailed 2-sample $t$-test: $t=1.69 ; \mathrm{df}=34$, $\mathrm{p}=0.05$; Fig. 4). Consequently, we found no significant difference in the proportionate contribution of acidified and reference oysters to the total consumed between choice and no-choice trials $\left(\chi^{2}=1.6, \mathrm{df}=1\right.$, $\mathrm{p}=0.21$ ). On average, in no-choice experiments, the time taken for $M$. marginalba to handle one oyster was $\sim 20 \%$ shorter for oysters from acidified $(36 \pm 2 \mathrm{~h})$ than reference $(45 \pm 2 \mathrm{~h})$ sites (1-tailed 2-sample $t$ test: $t=-3.38 ; \mathrm{df}=34, \mathrm{p}=0.001$ ).

\section{DISCUSSION}

Previously, shell dissolution has been observed among transplanted Saccostrea glomerata, after only $6 \mathrm{~h}$ exposure to ASS-affected waters in the laboratory (Dove \& Sammut 2007a), and after $40 \mathrm{~d}$ exposure in the field (Dove \& Sammut 2007b). Similar shell dissolution of gastropod shells has also been noted in acidified estuaries (Marshall et al. 2008). Based on these results, we hypothesized that multi-generational exposure of wild mangrove benthic invertebrates to estuarine acidification would reduce the strength of their exoskeleton. We also hypothesised that effects would be greater among species that are sessile or relatively sedentary than among those that are highly mobile and, among sessile invertebrates almost entirely dependent on armouring as an anti-predator defence, as this would increase susceptibility to predation. As predicted, within each of the estuaries sampled, the forces required to break mollusc shells were lower for molluscs from acidified than reference sites throughout the whole range of molluscs' sizes. However, we found no evidence that estuarine acidification reduces the strength of crab carapaces. 
Among sessile oysters, a reduction in shell strength resulted in a greater rate of predatory mortality.

Interestingly, the reduction in the shell strength of animals from acidified sites was of lower magnitude for Saccostrea glomerata than for Bembicium auratum. This is contrary to our predictions that the shells of sessile organism would be more impacted than those of animals with an ability to move out of ASSaffected waters. Whereas oysters remain attached to hard substrate following settlement, gastropods of several species, including $B$. auratum, can undergo up-shore migration during high tides to avoid predators, moving down the shore only when the tide retreats (e.g. Fairweather 1988, Reid 1988). Instead the shells of $S$. glomerata may be more resistant to dissolution by acidic ASS runoff than the shells of $B$. auratum. Whereas the shells of adult oysters are predominantly comprised of calcite (Stenzel 1964), the shell of $B$. auratum is of the more soluble aragonite (Taylor \& Reid 1990). Additionally, S. glomerata, which must rely almost entirely on shell thickening as anti-predator defence, might allocate more energy and resources to maintenance of the shell thickness under acidified conditions. Both oysters and gastropods are able to increase shell production in response to environmental pressure, such as predation, pollution, and mechanical stress (Currey \& Hughes 1982, Bibby et al. 2007, Newell et al. 2007). Mobile $B$. auratum, which combine armouring with avoidance strategies of anti-predator defence might not need to up-regulate shell-building to the same degree.

By contrast to the molluscs, mangrove crabs did not display weakened exoskeletons at the acidified sites. This may be due to a thick epicuticle, absent in molluscs, that isolates crustaceans from the exterior environment and allows them to regulate their internal $\mathrm{pH}$ and carbonate system in response to changes in water acidification (Cameron 1985, Ries et al. 2009). In a previous study, crabs were able to increase calcification rates while molluscs exhibited shell dissolution in response to $\mathrm{CO}_{2}$-induced acidification (Ries et al. 2009). Additionally, mangrove crabs may also be better able to withstand estuarine acidification as a consequence of their behaviour. For example, burrowing crabs can remain inside plugged burrows during the rising tide and thus avoid direct exposure to strongly ASS-acidified waters, while others have dispersion abilities that allow them to simply remain up on the shore above the water line (e.g. Eshky et al. 1995, Skov \& Hartnoll 2001). Previously, we found no difference in the abundances or size-structures of crabs between acidified and reference sites (Amaral et al. 2011) and Russell \& Helmke (2002) reported that acidic waters from ASS runoff did not negatively affect the survival of mud crabs Scylla serrata in the wild.

Overall, the impact of estuarine acidification on the shell strength of molluscs was smaller than predicted from previous short-term experiments exposing organisms to runoff from ASS soils (Dove \& Sammut $2007 a, b)$. In the laboratory, Saccostrea glomerata suffered shell degradation, soft tissue lesions and reduced filtration rates following just $6 \mathrm{~h}$ of exposure to water of pH 5.1 (Dove \& Sammut 2007a). In the field, up to $85 \%$ of small oysters were observed to have shell lesions following 2 mo of exposure to waters of average pH 5.47 (Dove \& Sammut 2007b). The weaker effects observed in the present study may be because it was conducted in a relatively dry period, during which the acidified sites had a $\mathrm{pH}$ of 6.52 to 6.98. During rainfall periods, when large amounts of runoff from ASS enter estuaries, $\mathrm{pH}$ can drop to 2 to 5 (Sammut et al. 1996, Russell \& Helmke 2002, Dove \& Sammut 2007b). Organisms may exhibit some capacity to recover in dry periods following major acidification events. Alternatively, organisms exposed to ASS-acidification over many generations may be able to adapt behaviourally and/or physiologically to the stressor. Mount et al. (1990) also reported that fish exposed for multiple generations to ASS runoff developed long-term physiological resistance to acidification.

Despite the relatively weak effect of acidification on the shell strength of oysters, we found that this translated into enhanced susceptibility to predatory mortality by a generalist benthic predator. Consistent with previous observations that even small changes in the structural defences of invertebrates can lead to substantially increased susceptibility to predation (e.g. Seed \& Hughes 1995, Cotton et al. 2004), weaker-shelled oysters from acidified sites were $67 \%$ more susceptible to predation by the muricid gastropod Morula marginalba than stronger-shelled oysters from reference sites. Three main lines of evidence suggest that the mechanism by which $M$. marginalba consumed more oysters from acidified than reference sites was primarily based on the biomechanics of shell strength. First, in no-choice experiments, we observed the handling time of an acidified oyster was on average $20 \%$ less than for a reference oyster. Second, even among no-choice trials, M. marginalba consumed more acidified than reference oysters, and in a similar proportion to that in choice trials. Third, in choice experiments M. marginalba attacked oysters in random order, with acidified and reference oysters equally as likely to be consumed first. Therefore, it is likely that the weakening 
of the shells of Bembicium auratum at the acidified sites would also lead to greater rates of predatory mortality amongst their populations, although predator avoidance behaviour in marine gastropods might compensate for a weakened shell (Cotton et al. 2004).

In addition to muricid gastropods, many species of crab consume prey items in inverse proportion to their shell strength (e.g. Hughes \& Elner 1979, Bishop \& Peterson 2006). Crabs are among the most common predators of molluscs (e.g. Juanes 1992, Seed \& Hughes 1995, Mascaro \& Seed 2001), and several large species, including Scylla serrata, are common within the estuaries sampled in the present study. These species may also gain advantage over oysters and gastropods with weakened shells by exposure to estuarine acidification. Such increased susceptibility of weakened oysters and gastropods to predation by a multitude of generalist predators may account for the reduced abundance and skewed sizefrequency distributions we have found for these species at acidified sites (Amaral et al. 2011).

In our predation experiments, we used predatory gastropods sourced from areas unaffected by ASS runoff. Nevertheless, given our demonstration of weakened shells among Bembicium auratum at acidified sites, Morula marginalba shells would likely be weakened, too. We expect that had we used M. marginalba from acidified sites, the outcome of experiments would not have been altered, as the gastropod's capacity to consume prey items is driven by its size but not its own shell strength. Crabs, by contrast, risk mechanical damage in opening large prey, and take this into account when choosing prey items (Juanes 1992, Seed \& Hughes 1995). Hence crabs that have chelae that are weakened by acidification might not experience the same benefit of weakened prey items as muricid gastropods. In the present study, we found that the carapace of Heloecius cordiformis was not weakened by acidification. Further studies would be required to ascertain whether predatory crabs, such as the portunids and Scylla serrata, similarly do not suffer the same reduction in exoskeleton strength as their molluscan prey items.

In summary, our investigations clearly demonstrate the potential for a human-mediated stressor, estuarine acidification, to alter predator-prey interactions that have evolved over thousands of years. Sustained exposure to acidic runoff from ASS reduced the exoskeleton strength of oysters and gastropods, rendering them more susceptible to generalist predators that consume prey in proportion to their shell strength. More mobile crabs, by contrast, did not suffer any reduction in exoskeleton strength, and if this pattern extends to predatory crabs, they may benefit from prey with weakened shells in predatory interactions. The present study highlights the importance of not just examining ecological impacts of stressors to individual species, but also to tropho-dynamics, as impacts can clearly propagate through ecological interactions.

Acknowledgements. We thank R. Hughes and 2 anonymous reviewers for helpful comments that improved the quality of the manuscript. We are in debt to B. Coates for help in the field. We acknowledge funding from Fundação para a Ciência e a Tecnologia, Portugal (project PEst-OE/MAR/UI0199/ 2011, and postdoctoral grant SFRH/BPD/44566/2008 to V.A.). All work complied with New South Wales and Australian government laws.

\section{LITERATURE CITED}

Amaral V, Cabral HN, Bishop MJ (2011) Resistance among wild invertebrate populations to recurrent estuarine acidification. Estuar Coast Shelf Sci 93:460-467

Bibby R, Cleall-Harding P, Rundle S, Widdicombe S, Spicer $\mathrm{J}$ (2007) Ocean acidification disrupts induced defences in the intertidal gastropod Littorina littorea. Biol Lett 3: 699-701

Bishop MJ, Peterson CH (2006) When r-selection may not predict introduced-species proliferation: predation of a nonnative oyster. Ecol Appl 16:718-730

Bishop MJ, Cole MR, Taylor SL, Wilkie EM, Kelaher BP (2008) Size-specific predation by dominant consumers maintains a 'trophic cul-de-sac'. Mar Ecol Prog Ser 354: 75-83

- Bishop MJ, Krassoi FR, McPherson RG, Brown KR, Summerhayes SA, Wilkie EM, O'Connor WA (2010) Change in wild-oyster assemblages of Port Stephens, NSW, Australia, since commencement of non-native Pacific oyster (Crassostrea gigas) aquaculture. Mar Freshw Res 61:714-723

Brown KM, Haight ES (1992) The foraging ecology of the Gulf of Mexico stone crab Menippe adina (Williams et Felder). J Exp Mar Biol Ecol 160:67-80

Byers JE (2002) Impact of non-indigenous species on natives enhanced by anthropogenic alteration of selection regimes. Oikos 97:449-458

Byers JE, Wright JT, Gribben PE (2010) Variable direct and indirect effects of a habitat-modifying invasive species on mortality of native fauna. Ecology 91:1787-1798

Cameron JN (1985) Post-moult calcification in the blue crab (Callinectes sapidus): relationships between apparent net $\mathrm{H}^{+}$excretion, calcium and bicarbonate. J Exp Biol 119:275-285

Cotton PA, Rundle SD, Smith KE (2004) Trait compensation in marine gastropods: shell shape, avoidance behavior, and susceptibility to predation. Ecology 85:1581-1584

Currey JD (1979) The effects of drying on the strength of mollusc shells. J Zool 188:301-308

Currey JD, Hughes RN (1982) Strength of the dogwhelk Nucella lapillus and the winkle Littorina littorea from different habitats. J Anim Ecol 51:47-56

Dent DL, Pons LJ (1995) A world perspective on acid sulfate soils. Geoderma 67:263-276 
Dove MC, Sammut J (2007a) Histological and feeding response of Sydney rock oysters, Saccostrea glomerata, to acid sulfate soil outflows. J Shellfish Res 26:509-518

Dove MC, Sammut J (2007b) Impacts of estuarine acidification on survival and growth of Sydney rock oysters Saccostrea glomerata (Gould 1850). J Shellfish Res 26: 519-527

Eshky AA, Atkinson RJA, Taylor AC (1995) Physiological ecology of crabs from Saudi-Arabian mangrove. Mar Ecol Prog Ser 126:83-95

Fairweather PG (1988) Movements of intertidal whelks (Morula marginalba and Thais orbita) in relation to availability of prey and shelter. Mar Biol 100:63-68

Fairweather PG, Underwood AJ (1983) The apparent diet of predators and biases due to different handling times of their prey. Oecologia 56:169-179

> Hartman KJ (2000) The influence of size on striped bass foraging. Mar Ecol Prog Ser 194:263-268

Hughes RN, Elner RW (1979) Tactics of a predator, Carcinus maenas, and morphological responses of the prey, $\mathrm{Nu}$ cella lapillus. J Anim Ecol 48:65-78

> Juanes F (1992) Why do decapod crustaceans prefer smallsized molluscan prey? Mar Ecol Prog Ser 87:239-249

Koh-Siang T (1993) Feeding ecology of common intertidal Muricidae (Mollusca: Neogastropoda) from the Burrup Peninsula, Western Australia. In: Wells FE, Walker DI, Jones DS (eds) The marine flora and fauna of Dampier, Western Australia. Western Australian Museum, Perth, p 173-192

Liszka D, Underwood AJ (1990) An exprimental design to determine preferences for gastropods shells by a hermitcrab. J Exp Mar Biol Ecol 137:47-62

> Magle S, Zhu J, Crooks KR (2005) Behavioral responses to repeated human intrusion by black-tailed prairie dogs (Cynomys ludovicianus). J Mammal 86:524-530

Marshall DJ, Santos JH, Leung KMY, Chak WH (2008) Correlations between gastropod shell dissolution and water chemical properties in a tropical estuary. Mar Environ Res 66:422-429

Mascaro M, Seed R (2001) Choice of prey size and species in Carcinus maenas (L.) feeding on four bivalves of contrasting shell morphology. Hydrobiologia 449:159-170

> Menge BA, Lubchenco J (1981) Community organization in temperate and tropical rocky intertidal habitats: prey refuge in relation to consumer pressure gradients. Ecol Monogr 51:429-450

Metcalf BM, Davis SJ, Ladd PG (2000) Adaptation behaviour by two bird species as a result of habituation to humans. Aust Bird Watch 18:306-312

Moran MJ (1980) Ecology and effects on its prey of the intertidal predatory whelk Morula marginalba Blainville. Unpublished PhD thesis, University of Sydney, Sydney

Moran MJ (1985) Effects of prey density, prey size and predator size on rates of feeding by an intertidal predatory gastropod Morula marginalba Blainville (Muricidae), on several species of prey. J Exp Mar Biol Ecol 90:97-105

Moran MJ, Fairweather PG, Underwood AJ (1984) Growth and mortality of the predatory intertidal whelk Morula marginalba Blainville (Muricidae): the effects of different species of prey. J Exp Mar Biol Ecol 75:1-17

> Mount DR, Swanson MJ, Breck JE, Farag AM, Bergman HL (1990) Responses of brook trout (Salvelinus fontinalis) fry to fluctuating acid, aluminum, and low calcium exposure. Can J Fish Aquat Sci 47:1623-1630

Murdoch WW, Oaten A (1975) Predation and population sta- bility. Adv Ecol Res 9:1-131

Naylor SD, Chapman GA, Atkinson G, Murphy CL and others (1998) Guidelines for the use of acid sulfate soil risk maps, 2nd edn. NSW Department of Land and Water Conservation, Sydney. Available at: www.environment. nsw.gov.au/resources/acidsulfatesoil/assmapsguide.pdf (accessed 14 September 2011)

Newell RIE, Kennedy VS, Shaw KS (2007) Comparative vulnerability to predators, and induced defense responses, of eastern oysters Crassostrea virginica and non-native Crassostrea ariakensis oysters in Chesapeake Bay. Mar Biol 152:449-460

NSW DPI (2006) Assay: a newsletter about acid sulfate soils, No. 40 Oct 2006. NSW Department of Primary Industries, Wollongbar. Available at: www.dpi.nsw.gov.au/_data/ assets/pdf_file/0005/168557/assay-40.pdf (accessed 14 September 2011)

NSW DPI (2008) Acid sulfate soils priority investigations for the lower hunter river estuary. Report to the Department of Environment, Water, Heritage and the Arts. Department of Primary Industries (Aquatic Habitat Rehabilitation), Port Stephens. Available at: www.dpi.nsw.gov.au/ fisheries/habitat/publications/threats/acid-sulphatesoils (accessed 14 September 2011)

NSW DPI (2009) Tilligerry Creek. Floodgate assessment. Report to the Hunter-Central Rivers, Catchment Management Authority, Project number HCR07_106, Orange. Available at: www.dpi.nsw.gov.au/_data/assets/pdf_file/ 0005/280922/Tilligerry-creek-floodgate-assessment-report. pdf (accessed 14 September 2011)

Reid DG (1988) The genera Bembicium and Risellopsis (Gastropoda: Littorinidae) in Australia and New Zealand. Rec Aust Mus 40:91-150

Ries JB, Cohen AL, McCorkle DC (2009) Marine calcifiers exhibit mixed responses to $\mathrm{CO}_{2}$-induced ocean acidification. Geology 37:1131-1134

Rodolfo-Metalpa R, Houlbreque F, Tambutte E, Boisson F and others (2011) Coral and mollusc resistance to ocean acidification adversely affected by warming. Nature Clim Change 1:308-312

> Russell DJ, Helmke SA (2002) Impacts of acid leachate on water quality and fisheries resources of a coastal creek in northern Australia. Mar Freshw Res 53:19-33

Sammut J, White I, Melville MD (1996) Acidification of an estuarine tributary in eastern Australia due to drainage of acid sulfate soils. Mar Freshw Res 47:669-684

Seed R, Hughes RN (1995) Criteria for prey size-selection in molluscivorous crabs with contrasting claw morphologies. J Exp Mar Biol Ecol 193:177-195

Seitz RD, Lipcius RN, Hines AH, Eggleston DB (2001) Density-dependent predation, habitat variation, and the persistence of marine bivalve prey. Ecology 82:2435-2451

Skov MW, Hartnoll RG (2001) Comparative suitability of binocular observation, burrow counting and excavation for the quantification of the mangrove fiddler crab Uca annulipes (H. Milne Edwards). Hydrobiologia 449: 201-212

Sponaugle S, Lawton P (1990) Portunid crab predation on juvenile hard clams: effects of substrate type and prey density. Mar Ecol Prog Ser 67:43-53

Stenzel HB (1964) Oysters: composition of larval shell. Science 145:155-156

Taylor JD (1990) Field observations of prey selection by the muricid gastropods Thais clavigera and Morula musiva feeding on the intertidal oyster Saccostrea cucullata. 
In: Morton BS (ed) Proceedings of the Second International Marine Biological Workshop: The Marine Flora and Fauna of Hong Kong and Southern China, Hong Kong, 1986. Hong Kong University Press, Hong Kong, p 837-855

Taylor DL, Eggleston DB (2000) Effects of hypoxia on an estuarine predator-prey interaction: foraging behavior and mutual interference in the blue crab Callinectes sapidus and the infaunal clam prey Mya arenaria. Mar Ecol Prog Ser 196:221-237

Taylor JD, Reid DG (1990) Shell microstructure and mineralogy of the Littorinidae: ecological and evolutionary significance. Hydrobiologia 193:199-215

Tulau MJ (1999) Acid sulfate soil management priority areas

Editorial responsibility: Roger Hughes,

Bangor, UK in the lower Hastings-Camden Haven floodplains. Report. Department of Land and Water Conservation, Sydney. Available at: www.dnr.nsw.gov.au/care/soil/as_soils/ pdfs/ass_hastings.pdf (accessed 14 September 2011)

Vermeij GJ (1982) Unsuccessful predation and evolution. Am Nat 120:701-720

Vermeij GJ (1987) The dispersal barrier in the tropical Pacific: implications for molluscan speciation and extinction. Evolution 41:1046-1058

Vermeij GJ (1994) The evolutionary interaction among species: selection, escalation, and coevolution. Annu Rev Ecol Syst 25:219-236

Zar JH (1984) Biostatistical analysis. Prentice-Hall, Englewood Cliffs, NJ

Submitted: June 1, 2011; Accepted: November 9, 2011

Proofs received from author(s): January 16, 2012 